\title{
Students Evaluation \& Teachers Trust: A Fear of Insignificance
}

\author{
Sheikh Raheel Manzoor \\ Lecturer, Institute of Management Sciences, Kohat University of Science \& Technology, \\ Kohat, KPK- Pakistan
}

Syed Habib Shah

Lecturer, Institute of Management Sciences, Kohat University of Science \& Technology,

Kohat, KPK- Pakistan

Dr. HafizUllah

Lecturer ,Institute of Management Sciences, Kohat University of Science \& Technology, Kohat. KPK- Pakistan

\section{Zulqarnain Muhammad Ahmad}

Lecturer ,Institute of Management Sciences, Kohat University of Science \& Technology,

Kohat. KPK- Pakistan

\author{
Inamullah
}

Assistant engineer, Pakistan Atomic Energy commission, Islamabad

Accepted: May 29, 2012 Published: June 27, 2012

Doi:10.5296/ijhrs.v2i2.2010ＵRL: http://dx.doi.org/10.5296/ijhrs.v2i2.2010

\begin{abstract}
This research study analyzes the teacher trust on student's evaluation about the staff members of Peshawar University and Kohat University of Science and Technology (KUST), Khyber Pakhtunkhwa (KPK), Province of Pakistan. Total 250 sets of questionnaires were personally delivered on random basis to the lecturers, assistant professors and professors of KUST and
\end{abstract}


Peshawar University. The collected information was regarding teacher's perception on student's evaluation. Results of the study were interpreted through simple bar chart and frequency distribution table to analyze the different responses of the respondents. There is clear evidence that the respondents highly trust on student's evaluation.

Keywords: Teacher Grade, Teacher Leniency, Teacher Evaluation

\section{Introduction}

Now-a-days quality enhancement and its maintenance is the important goal of every institution. The main purpose behind the application of quality standards is to perform it systematically. According to Freed, Klugman and Fife (1997) "Quality principals are defined as a personal philosophy and an organizational culture that uses scientific measurement of outcome, systematic management techniques, and collaboration to achieve an institution mission". The factors stressed by (Freed, Klugman \& Fife, 1997) are vision, mission and outcomes; system dependent; transformation leadership; systematic individual development, decision based on facts; delegated decision making; collaboration; plan for change and supportive leader. Thus a plan roadmap is essential for the survival of the institution. There is cut throat competition among different departments and institution in every passing day due to change in system (Sirvanci, 2004; Wood, 2007).

The leader should have effective communication skills and should be able to understand the need of stake holders. Managing quality of the higher education system is a complex task. Therefore Higher Education Commission (HEC) of Pakistan created quality assurance department is to maintain quality in the education industry of Pakistan and HEC of Pakistan regulate it. According to HEC "The key factors influencing the quality of higher education commission is the quality of faculty, curriculum standard, technological infrastructure available, research environment, accreditation regime and administrative policies and procedures implemented in institutions of higher learning". Thus, this study focuses on the teacher's expression about student's evaluations at Peshawar University and Kohat University of Science and Technology (KUST), Khyber Pakhtunkhwa (KPK), Pakistan. Peshawar University consists of 40 departments and KUST consists of 20 departments around 300 faculty members from lecturers to professors, having student's strength of around 5000.

Keeping in view the growing importance of quality education HEC Pakistan has established a quality enhancement cell (QEC) that is responsible for measuring and controlling the total quality education management of the Peshawar University and KUST. For this purpose quality enhancement cell take multiple steps to ensure quality education by imparting relevant training to teachers, administration and staff members. However, their main focus is on teachers performance that play the most important and strategic role in imparting quality education. The external stakeholders especially students decide their future education on the basis of faculty available and their strength of qualification that a university owns. This trend has put tremendous pressure on teaching profession, and demand a kind of reward for which the students pay. At the same time criteria for hiring a lecturer at university level is gone one step further from master to Ms/M.phil for meeting the growing demand and expectation of quality education. Moreover the students are greatly empowered at university level to gauge 
and evaluate their relevant teachers performance at subject teaches.

The QEC take semester wise performance evaluation report of teachers marked by the relevant students. This evaluation is given high importance by the QEC and the teachers are called on by the Vice Chancellor's in case his/her evaluation is not satisfactory. This quest for quality enhancement in education has created a debating issue, because many of the faculty members argue that students take undue advantage of this empowerment and they are not sincere to evaluate the performance of faculty on the basis of their efforts, hard work and intellectual capability. They are on the view that those teachers who award good grads receive positive evaluation report and those teachers who keep merit receive weak evaluation report. This trend of students according to some faculty members beneath the efficiency of teachers and they feel a Fear of Insignificance. They also are on the view that some efficient teachers also award good grads to those students whose performance is sluggish, in hope that students will send positive evaluation report in his favor. Many teachers who receive weak evaluations reports show lack of interest in the subject they teach and indulge themselves in other managerial activities to show their strength in front of QEC. They also to create good relationship with top management for the purpose to cover the humiliation provided by the students and to avoid the "Fear of Insignificance" as a teacher.

The students consider this evaluation a magic to pursue their career the way they want not the way teachers demand. Some teachers award good grads without proper check of student's performance and receive remarkable evaluation reports in turn. Thus, this paper will investigate the reality of expressions that some faculty members have and will provide the answer to the problem "Should Teachers Trust Students Evaluation" at Peshawar University and KUST, KPK, Pakistan. The main objectives of this study are to find out how teachers view students evaluation of their performance? Do teachers trust their evaluation or not? This study would have of vital importance for the academician, Scholars, Establishments of universities and itself for the Quality enhancement cell who check and supervises quality education at Peshawar University and KUST, KPK, Pakistan. More over this study will help to clarify the reservations of some angry faculty members who constantly complaint and speak against this trend of students empowerment.

\section{Literature Review}

Quality would be viewed differently by the internal and external stakeholders at the same time (Becket \& Brookes, 2008). In case of higher education system, external stake holders are customers, which are usually concerned about the quality assurance, that the offered product will give usefully results as promised by the institution (Bohran \& Ziarati, 2002). In order to guarantee such future security external government bodies offer their services by providing certification or recognition to the institutions or universities. Thus education commission when committed to quality gives refuge to the institutions (Harvey, 2005). The internal stakeholders of an institution are the faculty members, researchers, administration and staff members. There are more concerned about the quality enhancement (Mckay \& Kember, 1999).

To achieve the set standard, Quality management has to maintain its check on internal stakeholders importantly teaching and course material of the faculty. Due to Extensive 
competition, quality education is a major concern (Koslowski, 2006). This trend attracting many internal and external stakeholders, because stakeholders are educated and they require answers from the institutions (Fuhrman \& Elmore, 2004). Harvey and Green (1993) created four perspectives of quality in higher education. According to him quality as excellence refers to the distinctive and unique position created by the institution, quality as fitness for purpose focuses on matching of customers knowledge, understanding and skills with the industry demand, means to fill the gape between customers knowledge and industry requirements. Quality as value for money refers to the expectation of institution in term of business and profit, and lastly quality as transformation is when the institution adopts strategic changes to gain a niche in the industry (Harvey \& Green, 1993).

According to Lomas (2007) quality enhancement and quality assurance has been attached with the higher education system now. To explain the difference between quality enhancement and quality assurance, the quality enhancement means continuous improvement in the institution system where as quality assurance caters to the standards maintain by the institutions through check of external bodies (Biggs, 2003). Separate departments are maintained for quality enhancement and assurance by the higher education commission to avoid ambiguity on updating the curriculum and to keep check on the standards of the institutions (Lomas, 2007). Bradely (1993) provided a model of application of total quality management at the higher education. The concept pillar was introduced by Creech (1994).

Hansson and Klefsjo (2003) defines Total quality management as "Management strategy that has inter related components, namely: Core values, Techniques, and Tools" Total quality management should be viewed as TQE (Total Quality Education) stated by (Scrabec, 2000). Dr.W.Edwards Deming was the first scholar to introduce the concept of total quality management and the need of implementing quality control checks in every organization (Bonstingl, 1992).

According to Owens (2001) total and continuous quality improvement is seen as journey not as destination and as such has no real beginning or endings. Total quality management has been seen as managerial tool to fix the problem relating to services as well as approaches in education industry and it can be implemented in education industry (Vankatraman, 2007; Peat, 2005). Concluding, the entire procedure of TQM is stress is team work, efficient and effective methods with improving internal environment of the institution (Venkatraman, 2007). Applying TQM concept in education, the students will be convinced that they will be prepared for the market place (Soni, Chaubey \& Rayan, 2000). Increase in competition and development of the education industry lead to shortage of resources that gives birth to a thought to get maximum benefit from the resources available. The most obvious of which the faculty, gets offend as their level of authority and their methods of instructions changes leading to low morale. Weak implementation and focus of this new system could lead to worst outcomes (Raelin, 2003; Antony \& Preece, 2002).

\section{Research Methodology}

This study took place at the two universities of KPK, Pakistan namely KUST and Peshawar University. These Universities are working under the control of HEC of Pakistan. The total 250 sets of questionnaires (125) in each University were personally delivered on random 
basis to the lectures, assistant professors and professors. Total 200 usable questionnaires (100) from both Universities were returned at a response rate of $80 \%$ each. There were 42 female and 158 male teachers respond to the questionnaire. Respondents ranged in age from their early $25 \mathrm{~s}$ to over 50 , although the majorities were in their $30 \mathrm{~s}$ and $40 \mathrm{~s}$. The average age was thirty six. The majority of the teachers were Pakhtun. More then half were married. The major subject areas by the highest number of teachers were Management Science, Information Technology, Economics, Chemistry and English. The Male represents 158 of the total sample 200 which shows $79 \%$, and Female represents 42 of the total sample 200 which represents $21 \%$. There were more men than women in the sample. This study was cross sectional, unit of analysis was individual and researcher's interference was minimal. The collected data was uploaded in SPSS (Statistical Package for Social Sciences) version 16.0.

\section{Data, Presentation, Analysis \& Interpretation}

\section{Table 1}

\section{Age * Gender Crosstabulation}

\begin{tabular}{|c|c|c|c|c|}
\hline \multicolumn{2}{|c|}{ Count } & & & \multirow[b]{3}{*}{ Total } \\
\hline & & \multicolumn{2}{|c|}{ Gender } & \\
\hline & & Male & Female & \\
\hline \multirow[t]{3}{*}{ Age } & $25-35$ & 114 & 28 & 142 \\
\hline & $35-45$ & 30 & 11 & 41 \\
\hline & $\begin{array}{l}46 \\
\text { above }\end{array}$ & 14 & 3 & 17 \\
\hline \multicolumn{2}{|c|}{ Total } & 158 & 42 & 200 \\
\hline
\end{tabular}

The above table shows the cross tabulation of age and gender of male and female staff members of KUST and Peshawar University. The Male represents 158 of the total sample 200 which shows $79 \%$, and Female represents 42 of the total sample 200 which represents $21 \%$. Age was categorized in 3 categories; from 25-30 years there were 114 male and 28 females which represent $57 \%$ and $14 \%$ of the total sample 200 respectively. At the age of $35-45$ there were 30 male and 11 females which demonstrate $15 \%$ and $5 \%$ of the total sample 200 . At the age of 46 and above 14 represents male and 03 represent female which shows $7 \%$ and $1.5 \%$ of the total sample 200 . 
Table 2

Gender * Designation Cross tabulation

\begin{tabular}{|l|l|l|l|l|l|}
\cline { 3 - 5 } \multicolumn{1}{c|}{ Count } & \multicolumn{2}{|l|}{} & \\
\hline & & \multicolumn{2}{|l|}{ Designation } & \\
\cline { 3 - 5 } & & Lecturer & $\begin{array}{l}\text { Assistant } \\
\text { Prof }\end{array}$ & Professor & Total \\
\hline Gender & Male & 116 & 28 & 14 & 158 \\
& Female & 30 & 9 & 3 & 42 \\
Total & 146 & 37 & 17 & 200 \\
\hline
\end{tabular}

Table 2 shows the cross tabulation of management level and gender of the staff member of KUST and Peshawar University. The management level comprised on employee Lecturers, Assistant Professors and Professors. Top level staff members were included in the category of Professors, Middle level manager staff members were categorized in Assistant Professors and Lecturers are included in Low level manager staff. Top level staff members were 17 in which 14 represents male and 03 represents female out of 200 which shows $8.5 \%$ of the total. Medium level staff members were 37 in which male were 28 and female were 09 out of 200 which shows $18.5 \%$ of the total. Low level staff members were 146 in which male represents 116 and female represents 30 out of 200 which show $73 \%$ of the total.

1. Awarding good grades to the students not on the basis of performance results in positive evaluation of teachers?

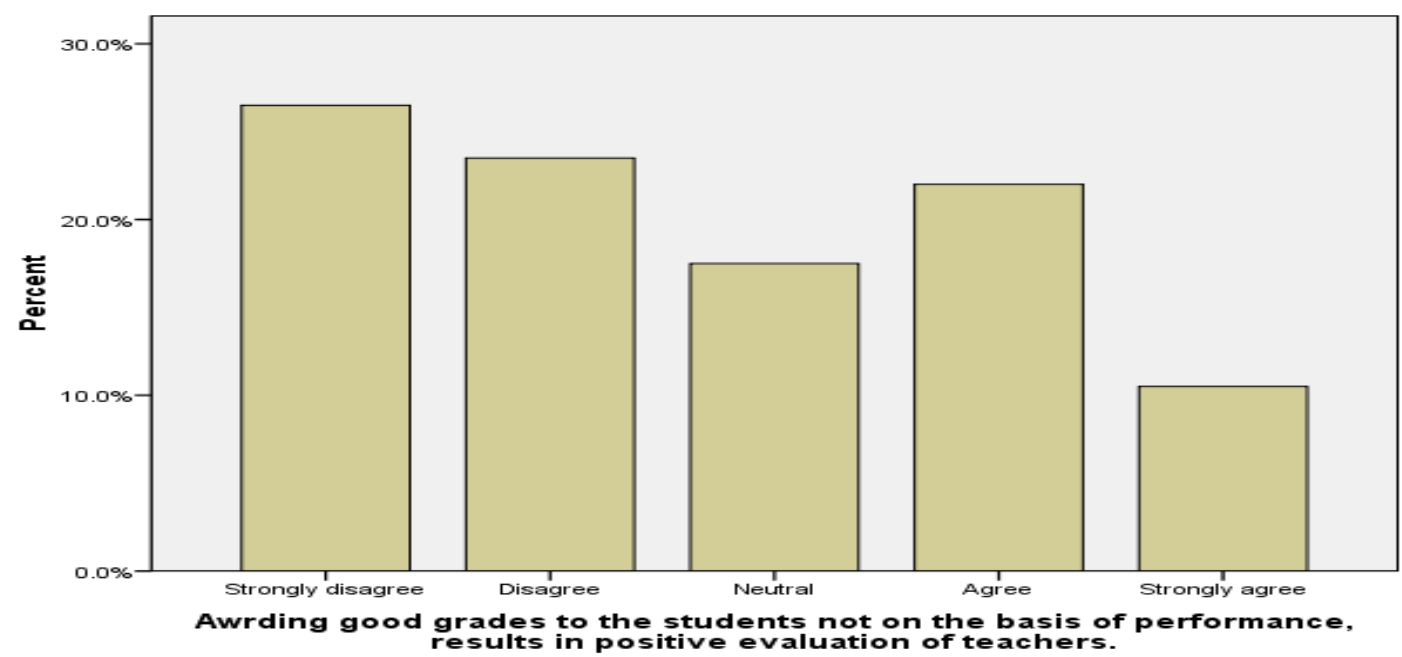




\begin{tabular}{|c|c|c|c|c|c|}
\hline & & Frequency & Percent & $\begin{array}{l}\text { Valid } \\
\text { Percent }\end{array}$ & $\begin{array}{l}\text { Cumulati } \\
\text { ve } \\
\text { Percent }\end{array}$ \\
\hline \multirow[t]{6}{*}{ Valid } & $\begin{array}{l}\text { Strongly } \\
\text { disagree }\end{array}$ & 53 & 26.5 & 26.5 & 26.5 \\
\hline & Disagree & 47 & 23.5 & 23.5 & 50.0 \\
\hline & Neutral & 35 & 17.5 & 17.5 & 67.5 \\
\hline & Agree & 44 & 22.0 & 22.0 & 89.5 \\
\hline & Strongly agree & 21 & 10.5 & 10.5 & 100.0 \\
\hline & Total & 200 & 100.0 & 100.0 & \\
\hline
\end{tabular}

The result of the $1^{\text {st }}$ question of the study demonstrates that $53 \%$ of the respondents strongly disagree, $47 \%$ respondents are disagree, $35 \%$ respondents are neutral, $44 \%$ respondents are agree and $21 \%$ respondents are strongly agree on Awarding good grades to the students not on the basis of performance results in positive evaluation of teachers.

2. Awarding grads to students on the basis of their performance result in weak evaluation of teachers?

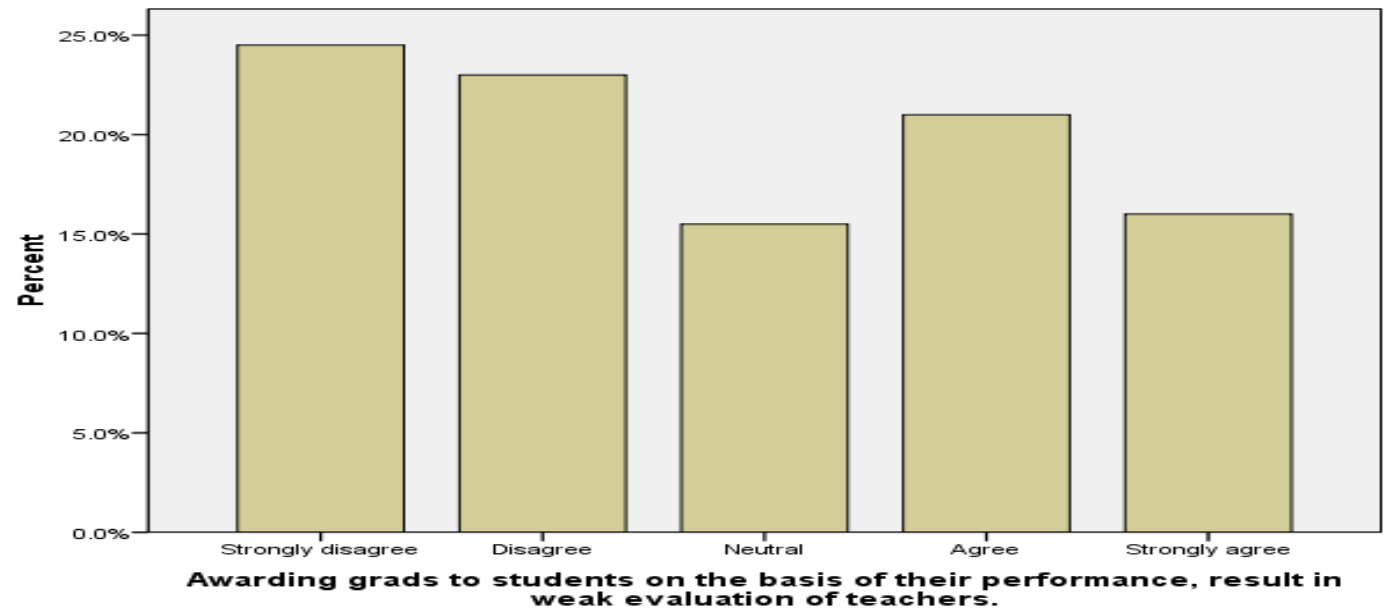




\begin{tabular}{|l|l|l|l|l|}
\hline & $\begin{array}{l}\text { Frequenc } \\
\text { y }\end{array}$ & Percent & $\begin{array}{l}\text { Valid } \\
\text { Percent }\end{array}$ & $\begin{array}{l}\text { Cumulative } \\
\text { Percent }\end{array}$ \\
\hline $\begin{array}{lllll}\text { Strongly } \\
\text { disagree }\end{array}$ & 49 & 24.5 & 24.5 & 24.5 \\
Disagree & 46 & 23.0 & 23.0 & 47.5 \\
Neutral & 31 & 15.5 & 15.5 & 63.0 \\
Agree & 42 & 21.0 & 21.0 & 84.0 \\
Strongly agree & 32 & 16.0 & 16.0 & 100.0 \\
Total & 200 & 100.0 & 100.0 & \\
\hline
\end{tabular}

The result of the 2nd question of the study demonstrates that $49 \%$ of the respondents strongly disagree, $46 \%$ respondents are disagree, $31 \%$ respondents are neutral, $42 \%$ respondents are agree and $32 \%$ respondents are strongly agree on Awarding grads to students on the basis of their performance result in weak evaluation of teachers.

3. Leniency of teachers due to fear of weak evaluation leads to positive evaluation of teachers?

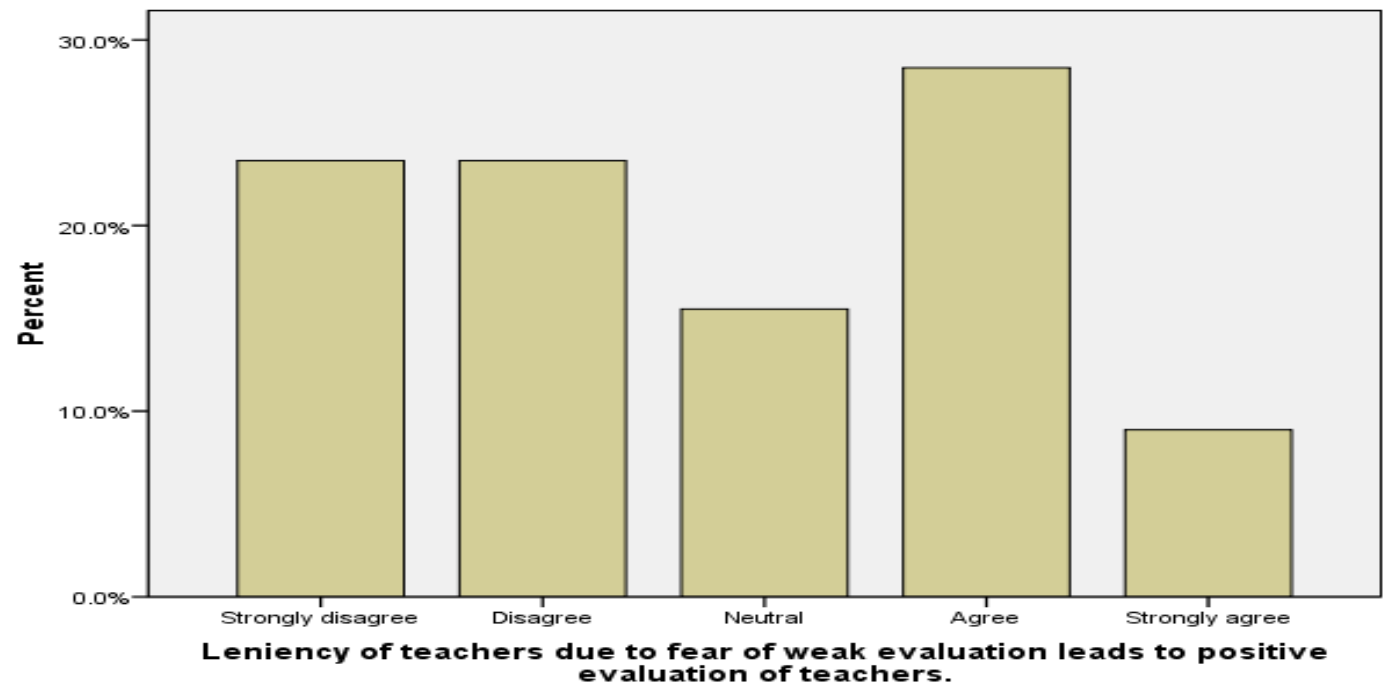




\begin{tabular}{|l|l|l|l|l|}
\hline & $\begin{array}{l}\text { Frequenc } \\
\mathrm{y}\end{array}$ & Percent & $\begin{array}{l}\text { Valid } \\
\text { Percent }\end{array}$ & $\begin{array}{l}\text { Cumulative } \\
\text { Percent }\end{array}$ \\
\hline Strongly & 47 & 23.5 & 23.5 & 23.5 \\
disagree & 47 & 23.5 & 23.5 & 47.0 \\
Disagree & 47 & 15.5 & 15.5 & 62.5 \\
Neutral & 31 & 28.5 & 28.5 & 91.0 \\
Agree & 57 & 9.0 & 9.0 & 100.0 \\
Strongly agree & 18 & 100.0 & 100.0 & \\
Total & 200 & \multicolumn{3}{|l}{} \\
\hline
\end{tabular}

The result of the 3rd question of the study demonstrates that $47 \%$ of the respondents strongly disagree, $47 \%$ respondents are disagree, $31 \%$ respondents are neutral, 57\% respondents are agree and $18 \%$ respondents are strongly agree on Leniency of teachers due to fear of weak evaluation leads to positive evaluation of teachers.

4. Strictness of teachers to maintain discipline in class leads to weak evaluation of teachers.

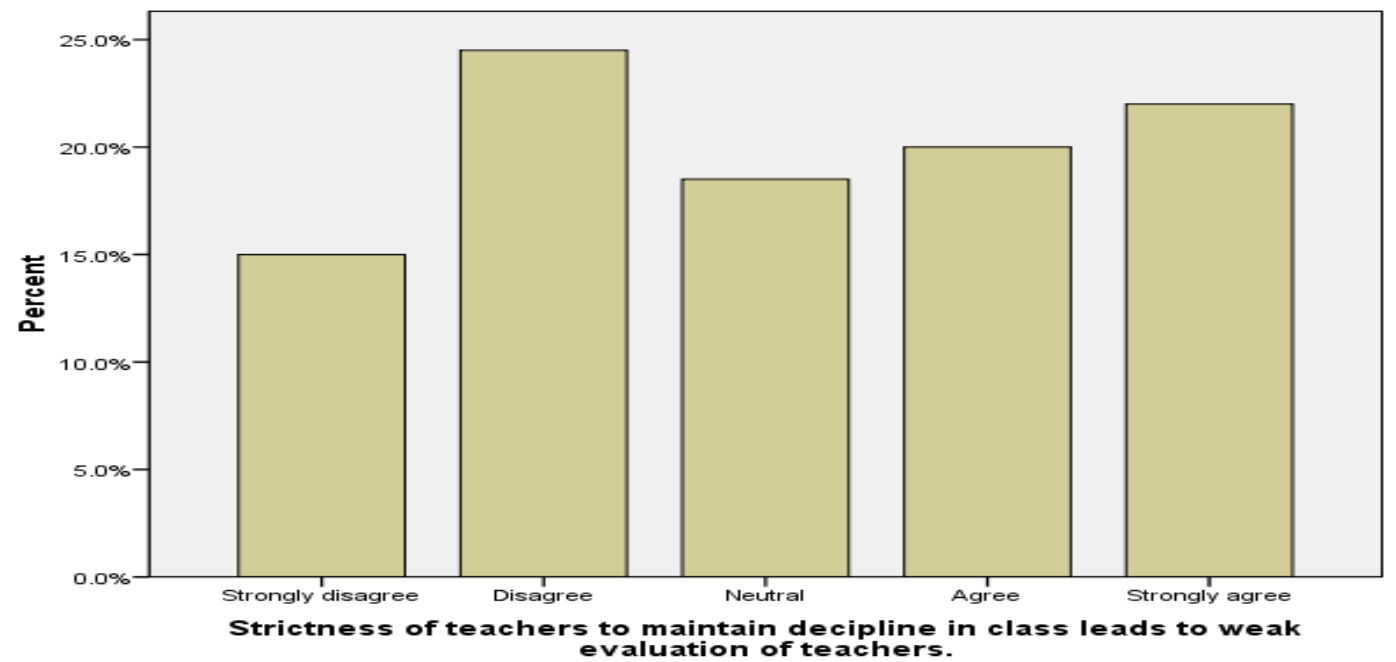




\begin{tabular}{|l|l|l|l|l|}
\hline & $\begin{array}{l}\text { Frequenc } \\
\mathrm{y}\end{array}$ & Percent & $\begin{array}{l}\text { Valid } \\
\text { Percent }\end{array}$ & $\begin{array}{l}\text { Cumulative } \\
\text { Percent }\end{array}$ \\
\hline Strongly & 30 & 15.0 & 15.0 & 15.0 \\
disagree & 49 & 24.5 & 24.5 & 39.5 \\
Disagree & 37 & 18.5 & 18.5 & 58.0 \\
Neutral & 40 & 20.0 & 20.0 & 78.0 \\
Agree & 44 & 22.0 & 22.0 & 100.0 \\
Strongly agree & 200 & 100.0 & 100.0 & \\
Total & &
\end{tabular}

The result of the $4^{\text {th }}$ question of the study demonstrates that $30 \%$ of the respondents strongly disagree, $49 \%$ respondents are disagree, $37 \%$ respondents are neutral, $40 \%$ respondents are agree and $44 \%$ respondents are strongly agree on Strictness of teachers to maintain discipline in class leads to weak evaluation of teachers.

5. Good teaching method and effective communication skills lead to positive evaluation of teachers?

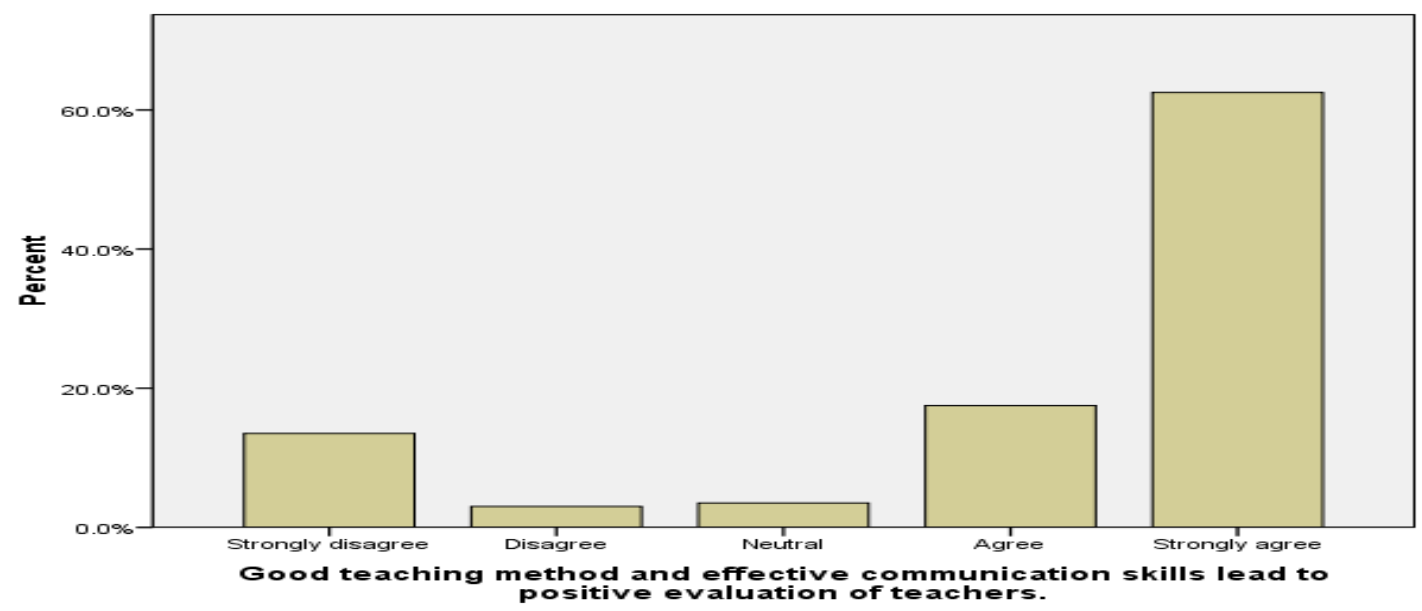




\begin{tabular}{|l|l|l|l|l|}
\hline & $\begin{array}{l}\text { Frequenc } \\
\mathrm{y}\end{array}$ & Percent & $\begin{array}{l}\text { Valid } \\
\text { Percent }\end{array}$ & Cumulative Percent \\
\hline Strongly & 27 & 13.5 & 13.5 & 13.5 \\
disagree & & 3.0 & 3.0 & 16.5 \\
Disagree & 6 & 3.5 & 3.5 & 20.0 \\
Neutral & 7 & 17.5 & 17.5 & 37.5 \\
Agree & 35 & 62.5 & 62.5 & 100.0 \\
Strongly agree & 125 & 100.0 & 100.0 & \\
Total & 200 & \multicolumn{3}{|l}{} \\
\hline
\end{tabular}

The result of the $5^{\text {th }}$ question of the study demonstrates that $27 \%$ of the respondents strongly disagree, $06 \%$ respondents are disagree, $07 \%$ respondents are neutral, 35\% respondents are agree and $125 \%$ respondents are strongly agree on Good teaching method and effective communication skills lead to positive evaluation of teachers.

6. Good relation with teachers leads to positive evaluation of teachers?

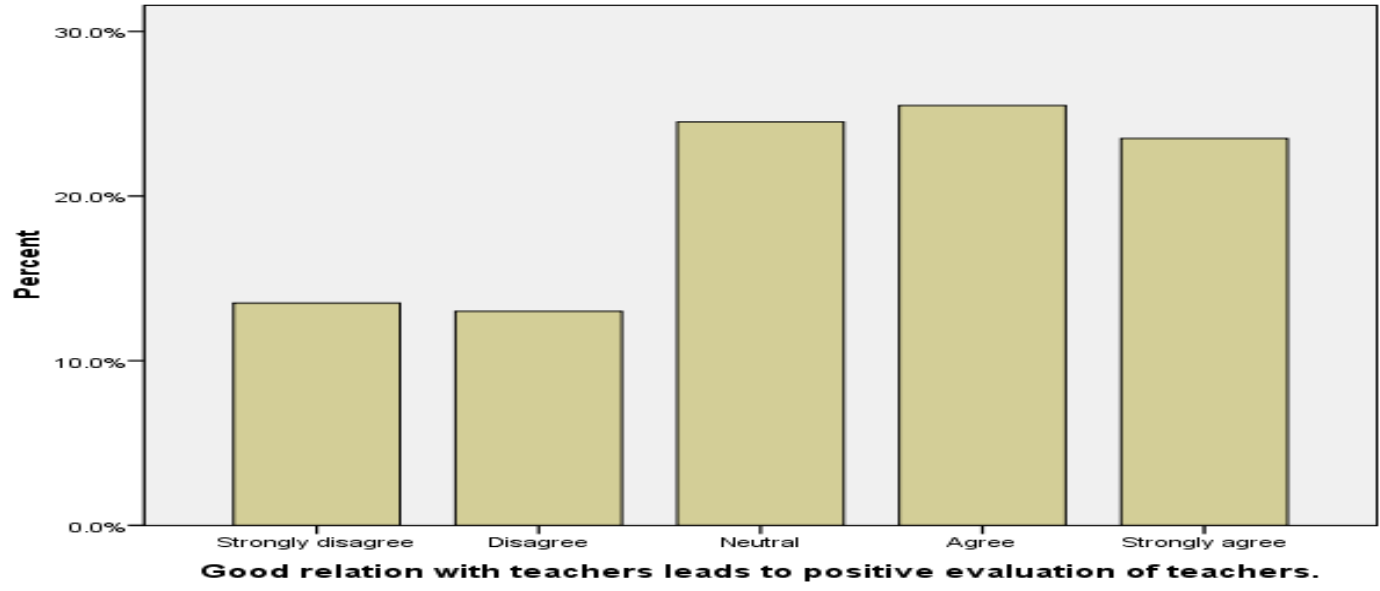




\begin{tabular}{|l|l|l|l|l|}
\hline & $\begin{array}{l}\text { Frequenc } \\
\text { y }\end{array}$ & Percent & $\begin{array}{l}\text { Valid } \\
\text { Percent }\end{array}$ & $\begin{array}{l}\text { Cumulative } \\
\text { Percent }\end{array}$ \\
\hline $\begin{array}{l}\text { Strongly } \\
\text { disagree }\end{array}$ & 27 & 13.5 & 13.5 & 13.5 \\
Disagree & 26 & 13.0 & 13.0 & 26.5 \\
Neutral & 49 & 24.5 & 24.5 & 51.0 \\
Agree & 51 & 25.5 & 25.5 & 76.5 \\
Strongly agree & 47 & 23.5 & 23.5 & 100.0 \\
Total & 200 & 100.0 & 100.0 & \\
\hline
\end{tabular}

The result of the $6^{\text {th }}$ question of the study demonstrates that $27 \%$ of the respondents strongly disagree, $26 \%$ respondents are disagree, $49 \%$ respondents are neutral, $51 \%$ respondents are agree and $47 \%$ respondents are strongly agree on Good relation with teachers leads to positive evaluation of teachers.

7. I am satisfied, the way students evaluate my performance?

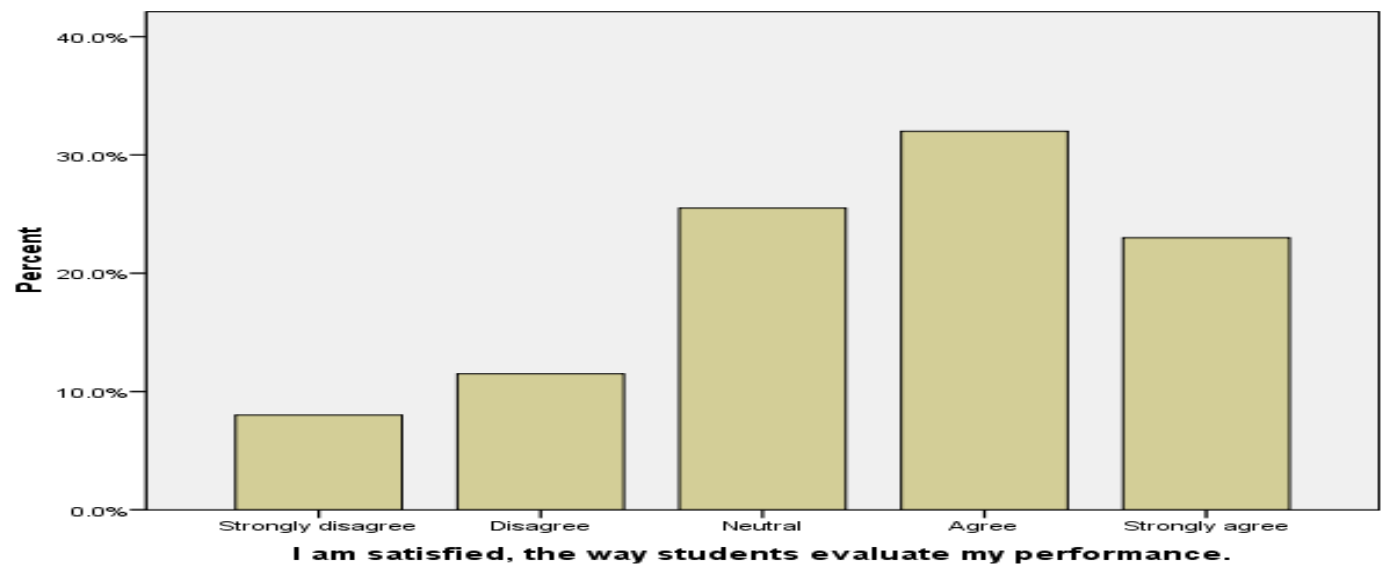




\begin{tabular}{|l|l|l|l|l|}
\hline & $\begin{array}{l}\text { Frequenc } \\
\mathrm{y}\end{array}$ & Percent & $\begin{array}{l}\text { Valid } \\
\text { Percent }\end{array}$ & $\begin{array}{l}\text { Cumulative } \\
\text { Percent }\end{array}$ \\
\hline $\begin{array}{c}\text { Valid Strongly } \\
\text { disagree }\end{array}$ & 16 & 8.0 & $\mathbf{8 . 0}$ & 8.0 \\
Disagree & 23 & 11.5 & 11.5 & 19.5 \\
Neutral & 51 & 25.5 & 25.5 & 45.0 \\
Agree & 64 & 32.0 & 32.0 & 77.0 \\
Strongly agree & 46 & 23.0 & 23.0 & 100.0 \\
Total & 200 & 100.0 & 100.0 & \\
\hline
\end{tabular}

The result of the $7^{\text {th }}$ question of the study demonstrates that $16 \%$ of the respondents strongly disagree, $23 \%$ respondents are disagree, $51 \%$ respondents are neutral, 64\% respondents are agree and $46 \%$ respondents are strongly agree on I am satisfied, the way students evaluate my performance.

\section{Conclusion}

Every organization has different set of tools to measure the quality of education. The most difficult part for an education sector is to set the performance standards. The better quality is only achievable if, the institutions recognize the correct performance mechanism. The result of the study clearly evidenced that teacher of KUST and Peshawar University strongly trusts on the student's evaluation. Teachers view regarding students' evaluation is very positive and they strappingly trust on their evaluation. This study strongly recommends that all the public and private sector organizations must have their quality management department. Quality management department make entire system very transparent and obvious. 


\section{References}

Becket, N. and Brookes, M. (2008). "Quality management practices in higher educationwhat quality are we actually enhancing". Oxford brookes university, Oxford. Journal of hospitability, leisure, sport and tourism education. Vol:7 No:1.

Biggs, J. (2003). "Teaching for Quality Learning at University, 2nd ed.". SRHE/Open University Press, Buckingham.

Bonstingl, J. J. (1992). "Schools of quality: An introduction to total quality management in Education". Alexandria, VA: Association for Supervision and Curriculum Development

Borahan, N. G. and Ziarati, R. (2002). "Developing Quality Criteria for Application in the Higher Education Sector in Turkey”. Total Quality Management, 13(7), 913-926.

Bradley, L. H. (1993). “Total quality management for schools”. Lancaster, PA: Technomic.

Freed, J. E., Klugman, M. R., \& Fife, J. D. (1997). “A culture of academic excellence: Implementing the quality principles in higher education". Washington, DC: George Washington University Press.

Fuhrman, S. H., \& Elmore, R. F. (2004). "Redesigning accountability systems for Education". New York: Teachers College Press.

Hansson, J., \& Klefsjo, B. (2003). “A core value model for implementing total quality management in small organizations”. TQM Magazine, 13, 71-81.

Harvey, L. and Green, D. (1993), "Defining quality". Assessment and Evaluation in Higher Education, Vol. 18 No. 1, pp. 9-34.

Harvey, L. (2005). "A History and Critique of Quality and Evaluation in the UK". Quality Assurance in Education, 13(4), 263-276.

Koslowski, A. Fred. (2006). "Quality and assessment in context: a brief review”. Quality assurance in education. Vol.14. No. 3.

Lomas, L. (2007). “Zen, motorcycle maintenance and quality in higher education”. Quality assurance in education. Kings college London, UK. Vol. 15 No.4

McKay, J. and Kember, D. (1999). "Quality Assurance Systems and Educational Development. Part 1: The limitations of quality control". Quality Assurance in Education, 7(1), 25-29. 
Owens, R.G. (2001). "Organizational Behavior in Education: Instructional Leadership and School Reform, 7th ed". Allyn \& Bacon, Boston, MA.

Peat, M., Taylor, C.E. and Franklin, S. (2005), "Re-engineering of undergraduate science curriculato emphasise development of lifelong learning skills". Innovations in Education and Teaching International, Vol. 42 No. 2, pp. 135-46.

Scrabec, Q. (2000). “A quality education is not customer driven”. Journal of Education for Business, 75, 298-302.

Sirvanci, M. B. (2004). "TQM implementation: Critical issues for TQM implementation in higher education”. Total Quality Management Magazine, 16, 382-386.

Soni, R. G., Chaubey, M. D., \& Ryan, J. C. (2000). "Implementing TQM in higher education institutions: A strategic management approach". Academy of Educational Leadership Journal, 4, 99-107.

Venkatraman, S. (2007). "A framework for implementing TQM in higher education programs". School of Information Management, Victoria University of Wellington, Wellington, New Zealand. Quality assurance in education, Vol: 15 No: 1.

Wood, R. C. (2007). "How strategic innovation really gets started”. Strategy \& Leadership, $35,21-27$. 